\title{
Paul's Radicalisation of Law-obedience in Romans 2: The plight of someone under the Law
}

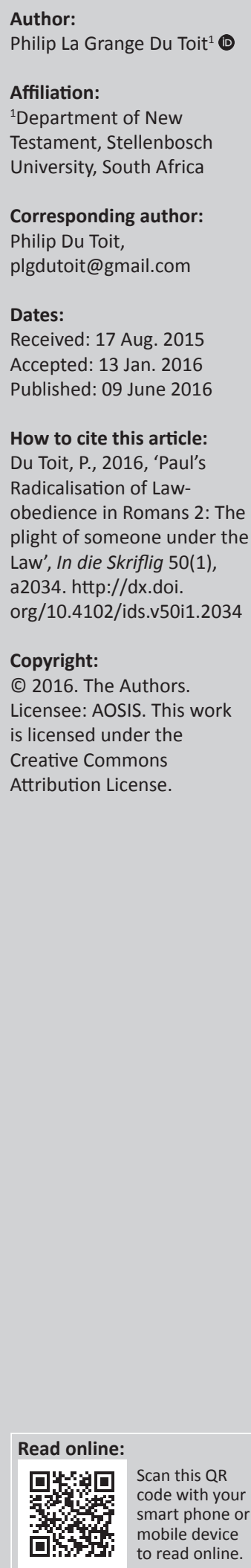

This article re-examines the tension between Paul's focus on the doing of the Law in relation to justification in Romans 2, and righteousness by faith in Romans 3:21-35. Taking into account current approaches to Romans 2, Paul's references to the doing of the Law are interpreted as forming part of the conditions for salvation and justification in the old era before Christ. The impossibility of doing the whole Law and the total depravity of all people constitute the plight of the old era under the Law. This plight is set in contrast with faith in Christ and anticipates the solution of faith in Christ, which marks the new condition for justification in the eschatologically new era in Christ.

\section{Introduction}

In the so-called New Perspective on Paul (NPP hereafter), the Ioudaioi ('Jews' or 'Judaeans') have progressively been portrayed in a more positive and non-legalistic way compared to a traditional, Lutheran reading of Paul. Justification, righteousness ${ }^{1}$ and obedience to the Law in Romans 2 lie close to the centre of this debate. In the NPP obedience to the Law is portrayed in such a way that it constitutes staying in the covenant and marking off identity, rather than meriting justification or salvation. The most challenging statement in Romans 2 probably lies in verse 13: 'it is not the hearers of the law who are righteous in God's sight, but the doers of the law who will be justified' (NRSV). How does this statement cohere with Paul's statements in Romans 3:20-21, ${ }^{2}$ that no one will be justified by deeds of the Law and that justification is apart from the Law? This article examines the latter problem afresh, and proposes a solution by taking current approaches to Romans 2 into account.

\section{Prevalent approaches to Law-obedience in Romans 2}

Although the problem of justification and obedience to the Law in Romans 2 has been interpreted in various ways over the centuries (see Moo 1996:140-141), there are at least five main approaches to these problems in recent scholarship. ${ }^{3}$ These approaches can be categorised (1) as interpreting obedience to the Law as theoretical and/or as unattainable (esp. 2:6-10, 13, 26); (2) as seeing obedience to the Law as being fulfilled in Christ, denoting believers in Christ (esp. v. 6-10, 13, 26, 29); (3) as reading the whole of Romans 2 in terms of an 'inner-Jewish' debate, representing two points of view; (4) as viewing the Ioudaios in verses 17-29 as a Gentile who wants to become a Ioudaios; and (5) as seeing the Ioudaios in verses 17-29 as referring to a Gentile rival missionary of Paul:

1. In the theoretical approach, the promise of eternal life for those who do good (2:7) is understood as fully valid, but only perfect obedience to the Law would suffice to justify someone before God, and the power of sin prevents anyone from doing good to the extent of meriting salvation. In this approach, it is normally argued in references to texts such as Galatians 3:10-13 and 5:3 that, according to Paul, no one is able to fulfil (e.g. Matera 2010:67-68; Moo 1996:140-142, 155-156; Osborne 2004:68) or has been able to fulfil (Westerholm 2004:253-264) those conditions. In a more pronounced variant of this approach, obedience to the Law is seen as purely hypothetical because of the impossibility of doing the whole Law (e.g. Calvin 2016:424; Thielman 1989:94-96; cf. Bruce [1985] 2008:96).

1.Although the closely related concepts of justification and righteousness form part of the equation here, space does not allow for a lengthy discussion of the nature of these concepts in Paul (i.e. forensic and transformative approaches). In this article it is presupposed that justification (mainly dikaioo in $2: 13 ; 3: 20,24,26,28$ ) involves the notion of final acquittal or being found innocent of wrongdoing (in Westerholm 2004:255; cf. Bauer et al. 2000, s.v. dikaioō, §2bß), and that righteousness (mainly dikaiosune in 3:21 $22,25,26$ ) denotes a redemptive state before God (Bauer et al. 2000, s.v. dikaiosunē, \$2) that is to be understood as a relationa concept and arguably involves both God's action and his gift of righteousness to people (cf. Dunn 1988:41-42; Moo 1996:74).

2.Further references to the book Romans will be indicated only by chapters and verses.

3.Cf. Ortlund's list (2009:324-329) of fourteen ways scholars have sought to square Paul's teaching on justification by faith with that of judgement according to works in general. 
2. A growing number of interpreters see obedience to the Law (v. 6-10, 13, 26, 29) as specifically pointing to believers in Christ. Only they are able to produce the works acceptable to God in judgement (e.g. Cranfield 1975:146-147, 155; Fitzmyer 1993:297; Schreiner [1998] 2005; Wright 2001). In this approach, obedience to the Law is understood as a result of justification by faith.

3. Following Sanders (1983:128) and Dunn (1988:108), Carras (1992) sees Romans 2 as representing an 'innerJewish debate'. He argues that the problem Paul addresses is neither legalism, nor is Paul's critique Christological (as in 9:30-32). For Carras (1992:193) the problem that Paul addresses is that the 'Jews' practice is inconsistent with central beliefs and convictions of the Jewish religion', and that the 'critic' in Romans 2 'misapplied the place of ancestry as it related to the judgement of God in a way that exceeded the Jews' historic priority and their inherent privileges of race' (p. 206). In this understanding Paul thus argues against the exclusivity of the Ioudaioi.

4. Theissen (2014:373-391) argues that 2:17-29 are not addressing a Ioudaios at all, but in fact concern a Gentile who wants to be called a Ioudaios and believes he has become a Ioudaios. Theissen contends that the person under discussion does not comply with the proper requirement of being a real Ioudaios, that is, having been circumcised on the eighth day. Similarly, Nanos (2014:26-53) argues that Paul writes in 2:17-29 to Gentiles who wanted to become Ioudaioi, but behaved hypocritically. Although Nanos (2014:49) contends that Paul did think it was possible for a Gentile to become a Ioudaios, he argues that Paul in Romans 2 portrays an ideal Jew ... who understands the real purpose of the visible signs of being the historical people of God and teacher among the nations'. For Nanos (2014:50), Paul calls for Christfollowing Gentiles to 'behave Jewishly' and 'internalize jewishness' without becoming actual Ioudaioi (p. 51).

5. While Campbell's approach (2012:382-393) overlaps to the above approach, he sees the Ioudaios in 2:17-29 specifically as 'a somewhat pompous rival missionary who is urging Paul's converts from paganism to convert fully to Judaism' (p. 390). Paul's intention would be to humiliate the position of this rival missionary in a Socratic way (Campbell 2012:391).

\section{Critiquing prevalent interpretations of Law-obedience in Romans 2}

While the approach in this article probably lies closest to the first approach above, it could be asked if 2:13, where justification is portrayed as being achieved on the basis of doing the Law, is given its full force. If Law-obedience is considered theoretical because of the impossibility of fully keeping it, how could Paul write that God will give 'eternal life' to those who by 'patiently doing good' seek for glory, honour and immortality (2:7), and give 'glory and honour and peace' to everyone who does good (v. 10)? By portraying justification by Law as theoretical or even hypothetical, it is not always clear whether justification by faith is supposed to undo the connection between Law-obedience and justification, or whether the doing of the Law is in some way still assumed to be applicable for a believer in Christ. It is therefore no wonder that some combine approaches in point 1 and 2 above, where Law-obedience is seen as both theoretical yet fulfilled and reapplied in a different way in Christ (e.g. Moo 1996:140-142). It could additionally be asked of the first approach whether the requirement to do the Law is only a requirement for Ioudaioi or for Gentiles also, and whether the requirement to do the Law only applies to the old age before Christ, or whether it is still applicable in the new age in Christ.

Regarding the second approach, one has to ask why Paul would deem it necessary to connect Law-obedience so closely to justification (esp. 2:13) in light of disconnecting the Law from a right standing with God elsewhere (e.g. 3:28; 6:14-15; 7:6). In other words, this approach, rather than alleviating the potential contradiction of the means of justification between Romans 2 and the rest of the letter, heightens such a potential contradiction. Why would Paul find it necessary to depict justification in terms of doing the Law in such explicit terms in Romans 2, if believers are not 'under the Law' any longer (6:14-15; cf. 1 Cor 9:20; Gl 4:5, 21; 5:18), and if righteousness is 'apart from the Law' according to $3: 21$ ?

In terms of the third approach, it could be asked whether the new eschatological era of faith in Christ is given its full force. If Paul's rhetorical aim is merely to address inappropriate conduct, beliefs or reliance on ancestry, why would the Christ event be so central or necessary in Paul's thought? If the position of the Ioudaioi toward the Law has not changed substantially in Christ, but merely represents a deeper understanding of what was already true in the Old Testament, why is a revelation (phaneroo ) of God's righteousness necessary in Christ (3:21)? This approach thus blurs the boundaries between the old age before Christ and the new age of faith in Christ.

There are several difficulties in the fourth approach. To reduce the inability of the Ioudaios in 2:17-29 to being a Gentile who cannot comply with the true requirement of circumcision (Theissen 2014), suppresses the force of the examples of sinful conduct that Paul lists in 2:21-24 (e.g. stealing, adultery, etc.). The criticism of the Law-observance of the Ioudaios in this passage is thus hardly that proper circumcision is lacking. Or if Paul had merely wanted to correct the hypocritical behaviour of Gentiles who wanted to become like Ioudaioi without becoming full Ioudaioi (Nanos 2014), why would it be necessary to put so much emphasis on obeying the Law, and how would such a notion relate to 3:21 that uncouples righteousness from Law-observance? Further, the same criticism of the third approach applies to this approach. If the position of the Ioudaioi in relation to the Law has not fundamentally changed in Christ, what is Christ's real significance for them, and what is then so 'revelational' about righteousness by faith (3:21)? In light of these questions, it makes more sense to see the Ioudaios in 2:17-29 as representing an actual Ioudaios (e.g. Dunn 1988:109; Moo 1996:159; Schreiner [1998] 2005:153-154; Wright 2002:446). 
Although Campbell (2012) sets forth an intriguing proposal (the fifth approach), it requires insider knowledge about Paul's rhetorical situation that is not testable. Campbell's theory (2012:391) further involves the assumption that 1:18-32 is not Paul's own thoughts, but part of his alleged opponent's inconsistent, aggressive rhetoric, an interpretation that cannot be derived from an intuitive or plain reading of the text of the letter to the Romans. The decision between which parts in the letter represent Paul's thoughts and which parts belong to the thoughts of his alleged rival missionary, remains arbitrary.

Another pertinent question that has to be asked about the prevailing approaches to Law-obedience in Romans 2, especially the third, fourth and fifth approaches, is to what extent a particular ideology or agenda lies behind such approaches. Could it be that an over-sensitivity to acknowledging a too close connection between Lawobedience and justification under the Ioudaioi, or for portraying the identity of the Ioudaioi in a pejorative way, would miss the depth of Paul's rhetorical aim? A sign of such an ideological reservation seems, for example, to lie behind Campbell's remark (2012:391) that the 'ghastly legalistic portrait of the generic Jew that has done so much damage in the history of the church can ... now be abandoned'. Kim (2010:329) goes so far as to argue that the fear of possibly being mistaken for an anti-Semite constitutes a 'theological shibboleth that hinders one from interpreting Paul's theology objectively'.

\section{Law-obedience and justification in Romans 2}

If the prevalent interpretations of Law-obedience in Romans 2 can be criticised, how can such criticism be overcome? An important principle is proposed in attempting to solve the difficulties in this passage to allow for the full force of Paul's notions about obtaining justification by doing the whole Law. Paul's emphasis on doing the Law can be traced back to Romans 1. Romans 1 ends with Paul's reference to death being deserved by those who do (Bauer et al. 2000, s.v. prassō, $\S 1 \mathrm{a}[\mathrm{X} 2]$; poieo, $\S 2 \mathrm{e}$ ) all kinds of sinful things (v. 32). The notion of doing is repeated in 2:2-3 (prassō) in the context of God's judgement. Romans 2:6 closely corresponds to Psalm 61:13 (Septuagint, LXX hereafter) and Proverbs 24:12 (LXX; cf. Job 34:11, LXX), pointing out that God rewards (Bauer et al. 2000, s.v. apodidomi, §4) or repays (New Revised Standard Version, [NRSV hereafter]; International Standard Version, [ISV hereafter]) everyone according to what they have done. This reward is defined as either 'eternal life' for those who do good (2:7) or as wrath and fury for those who do not (v. 8).

What Paul puts forward in Romans 1 to 2 strongly echoes Old Testament teaching. The theme of death being the punishment for those who do all kinds of sin (1:32) reminds of death being the ultimate consequence of $\sin$ (Gn 2:17; $3: 3,19)$ and death being the punishment for certain offences (e.g. Gn 17:14; Ex 12:15; 30:33, 38; Lv 7:20-27; 17:10; 18:29; $19: 8 ; 20: 6$; Nm 15:31). The idea of life being the reward for doing good (2:7) and being justified (NRSV; ISV; English Standard Version) or vindicated (Bauer et al. 2000, s.v. dikaioō, $\S 2 \mathrm{~b} \beta$; Moo 1996:147) on the basis of doing the Law (2:13), corresponds with similar notions elsewhere in Paul. In both Romans 10:5 and Galatians 3:12 Paul quotes Leviticus 18:5, which states that those who do the commandments of the Law would live by them (cf. Dt 4:1; Ezk 20:11, 13, 21; Neh 9:29). Regarding Leviticus 18:5, Milgrom (2004:201) notes that it is not God, but the laws themselves that give life to those who fulfil them (cf. Moo 2013:208). Although 'life' in Leviticus 18:5 probably focuses on temporal life (Hartley 1992:5), the references in Ezekiel 20:11, 13 and 21 to the same principle involve eternal life (Sailhamer 1992:346). It is thus quite possible that Leviticus 18:5 was interpreted as involving both temporal and eternal life (Gispen 1950:264). ${ }^{4}$ Paul's reference to 'eternal life' as the reward for doing the Law (2:7) seems to echo such an understanding. ${ }^{5}$ Yet such an understanding of these Old Testament texts would imply the reward of salvation for those who keep the commandments, a view that is indeed in conflict with the doctrine of justification by faith (cf. Rooker 2000:248).

Paul's admonition that circumcision compels one to do the Law (2:25; G1 5:3) relates to an existing notion held by some Ioudaioi that circumcision itself would be a passport to salvation (Barrett [1962] 1975:58; adopted by Cranfield 1975:172). The latter notion could in turn relate to the command that the person who was not circumcised had to be cut off from God's people, implying death (Gn 17:14). Nevertheless, Paul implies that the whole Law had to be done in order to obtain life (2:6) or vindication (v. 13). While the requirement to do the whole Law is explicit in Galatians 3:10 (quoting Dt 27:26, LXX) ${ }^{6}$ and Galatians 5:3, the same requirement can be derived from the context of Romans 2 . In 2:21-23 Paul lists a few examples of where he considers all Ioudaioi who lay claim on the Law to be breaking the Law. He thus implies that all Ioudaioi are breaking the Law in some way. By implication, only perfect obedience to the Law would secure one's status before God (cf. Bruce [1985] 2008:96; Moo 1996:156-157). If the latter is Paul's intention, the natural question that flows from it is why Paul would consider Lawobedience so important as to portray it as a condition for vindication (2:13). But before this question can be answered, the meaning of 2:28-29 has to be established.

\section{The circumcision of the heart as Law-obedience in Romans 2:28-29}

The last two verses of Romans 2 are often interpreted as a cryptic reference to the new position in Christ and the Spirit where the believer's heart is circumcised (e.g. Dunn 1988: 127-128; Moo 1996:174-175; Wright 2002:449). Yet, the expression en pneumati [in [the] spirit] is used together with

4. Hartley (1992:5) argues that this passage prepares the hearer for the fuller revelation of God, which involves eternal life (see Ezk 20:11, 13, 21).

5.It is noteworthy that when Paul later quotes Leviticus 18:5 directly (10:5), it is in the context of obtaining salvation $(10: 9-10,13)$.

6.The LXX differs from the Masoretic Text in that 'all' is added to 'the words of this law' (pasin tois logois tou nomou). 
kardias [of [the] heart], which rather places both terms in an anthropological domain. Even Paul's allusion to the meaning of the name Ioudaios [praise] in the expressions hou epainos ouk ex anthropōn all' ek tou theou [of whom the praise [is] not from men, but from God] underscores the notion that Paul is still relating to the identity of the Ioudaios (cf. Ervin 1984:113-115; Hultgren 2011:130-131; Ridderbos 1959:69). ${ }^{7}$

When Paul is speaking of the circumcision of the heart (2:29), such an expression is certainly derived from the Old Testament, for this concept is specifically mentioned in Leviticus 26:41; Deuteronomy 10:16; 30:6; Jeremiah 4:4 and 9:13-14, 25-26. Yet, the context of all these passages links the circumcision of the heart closely to conduct according to God's Law: actual obedience and doing the Law.

In Leviticus 26, the people's uncircumcised heart (v. 41) is set within the context of confessing their iniquity and the sin of their fathers (v. 40). A humbling attitude is certainly part of what is intended in realising the uncircumcision of their hearts ( $\mathrm{Lv} 26: 41)$, but the humbling of their uncircumcised heart entails that they shall, in God's words, 'make amends of their iniquity, because they dared to spurn my ordinances, and they abhorred my statutes' (v. 43, NRSV). In Leviticus 26:46 the people are then commanded to adhere to the statutes and ordinances and laws that the LORD established between himself and the people of Israel' (NRSV).

The urging to God's people to 'circumcise the foreskin' of their hearts in Deuteronomy 10:16 is preceded by God telling the Israelites what is required of them: they should fear God, walk in all his ways, love him and serve him with all their heart and soul (v. 12). Fundamental to this requirement is that they should keep the commandments and decrees of God (Dt 10:13). Circumcising their hearts (Dt 10:16) would by implication enable them to fulfil God's commandments and decrees. Yet, the circumcision of their hearts is also built on the basis of God's lordship (Dt 10:17), his justice and his love for strangers (v. 18). The circumcision of their hearts thus implies that his people should replicate these divine characteristics: they should also love strangers (Dt 10:19), they should fear the Lord, worship him alone, hold fast to him and swear by his name alone (v. 20), for he is their praise and their God who has done awesome things for his people and multiplied them (v. 21-22). Deuteronomy 11 then reiterates the practical execution of the circumcision of their hearts: 'You shall love the LORD your God, therefore, and keep his charge, his decrees, his ordinances, and his commandments always' (v. 1, NRSV). And again they are instructed: 'Keep, then, this entire commandment that I am commanding you today' (Dt 11:8, NRSV). The context of Deuteronomy 10 to 11 thus grounds the circumcision of the heart in both an attitude of reverence, love and commitment to God, and in the actual keeping of God's decrees, ordinances and his commandments (cf. Craigie [1976] 1983:364; Merrill 7.This understanding is strengthened by the fact that Paul's pun on the meaning of
loudaios (referring to 'praise' - as can be seen in Leah's remark in Gn 23:35) required some insider knowledge (cf. Wright 2002:449).
1994:207). The keeping of God's commandments is thus part of the 'covenant requirements' (Merrill 1994:208).

Deuteronomy 29 ends by pointing to both God's anger and every curse in this covenant that would result from the people's idolatry (v. 26-28). Deuteronomy 29:29 states that the secret things belong to the Lord and that the revealed things belong to God's people forever 'to observe all the words of this law' (NRSV). Deuteronomy 30 directly follows with the urging of the people to call the blessings and curses to mind, to return to the Lord and to obey him with all their heart and soul, just as the Lord commands them (v. 1-2). Deuteronomy 30:3 to 5 give an account of how God will restore the people's fortunes and gather them from where they are exiled. Part of what God will do is to circumcise the people's hearts in order that they would love God with all their heart and soul (Dt 30:6). God's enemies and those who persecute God's people will, however, be cursed (Dt 30:7). Then follows the result of God's circumcision of the heart: they will obey the Lord and observe his commandments (Dt 30:8). God's blessing on his people and the prosperity they will receive (Dt 30:9) are based on obeying the Lord and, in the Deuteronomist's words, 'by observing his commandments and decrees that are written in this book of the law, because you turn to the LORD your God with all your heart and with all your soul' (v. 10, NRSV). In Deuteronomy 30:16, the love of God is again connected to obeying God's commandments: by walking in his ways and by observing his commandments, decrees and ordinances. The keeping of the commandments in turn results in 'life' (cf. Lv 18:5). There is thus an inseparable relationship between life (Dt 30:6, 16), the circumcision of the heart (v. 6), the love for God (v. 6, 16), and the keeping of God's commandments (v. 8, 10, 16). Yet, Merrill (1994:421) refers to the requirement to love God with all your heart and soul (which by implication involves obedience to God's commands) as an 'impossible standard', and being 'the ideal of covenant behaviour, the one to be sought but never fully achieved'.

In Jeremiah 4 and 9, the connection between the circumcision of the heart and the keeping of the Law is even more explicit. Jeremiah 4 starts with the urging of Israel to return to God and to put away their abominations from God's presence (v. 1). If they change their conduct by swearing 'As the LORD lives' (NRSV) in truth, justice and in uprightness, then the nations shall be blessed by God and boast by him (Jr 4:2). The people are urged to break up fallow ground and not to sow among thorns (Jr 4:3). Then in Jeremiah 4:4, the people are commanded to circumcise themselves ${ }^{8}$ to God and to remove the foreskins of their hearts in order to avoid God's wrath because of the evil of their 'doings'.

In Jeremiah 9:13-14, God's people are reprimanded for forsaking the Law that God has set before them, for not obeying his voice, and for not walking in accordance with it. They have stubbornly followed their own hearts (which are uncircumcised by implication) and committed idolatry. In 8.Thompson (1980:215) shows that the Niphal originally had a reflexive sense (the LXX has: 'to God') 
the same context, God says in Jeremiah 9:25 to 26 'that days are coming when he will attend to all those who are circumcised, but are [actually] uncircumcised [in heart]', or to 'all those who are circumcised only in the foreskin' (v. 25, NRSV). In Jeremiah 9:25, Israel is depicted as 'uncircumcised in heart' and compared to the Gentile nations which are (literally) uncircumcised. The comparison of Israel with the Gentiles is obviously on the basis of their sinful conduct. Harrison ([1973] 1974:92) writes that the Ioudaioi 'though circumcised in body, had no real inner dedication to the spiritual ideals of Sinai'.

Apart from the close connection between the circumcision of the heart and the doing of the Law in the Old Testament, the concept of the human 'spirit' (ruach) is not foreign to the Old Testament either (e.g. Gn 41:8; 2 Ki 19:7; Job 7:11; Nm 16:22; Is 42:5). 2 Chronicles 28:12 reports of David's plans for the temple that he had 'in spirit' (en pneumati, LXX). While the human 'heart' (lebab) is used together with ruach as human quality in Joshua 2:11 and 5:1, ruach in these instances denotes human courage. Yet, in Psalm 77:6, the terms lebab and ruach are used together as human properties, which God must communicate with and search. The best example of where the terms lebab and ruach are used together is probably Deuteronomy 2:30, which tells of King Sihon of Heshbon, who did not allow the Israelites to pass through, for the Lord 'had hardened his spirit and made his heart defiant' (NRSV). An exceptionally clear example of where there exists a close link between obedience, the circumcision of the foreskin of the heart, God's creation of 'a holy spirit' in people, repentance, the cleaving to God and all his commandments, and the fulfilling of God's commandments, is found in Jubilees 1:22-25. ${ }^{9}$

Both the concepts of the human 'spirit' and the human 'heart', which have to be in line with God's will or commandments, are significant within the frame of reference of the Old Testament. Since Paul addresses a Ioudaios in 2:17-29, he would certainly anticipate an understanding of these concepts from an Old Testament point of view. By implication, the human 'heart' and 'spirit' must not be hardened or uncircumcised, but these human qualities or properties must be in line with God's Law. Rather than circumcision being something in the external, physical sphere, the true Ioudaios should be spiritually and inwardly capable of doing the Law.

\section{Law-obedience in Romans 2 in relation to faith in Romans 3}

In the above reading, the obedience to or the doing of the Law is a prominent theme throughout Romans 2, and is closely linked with eternal life (v. 7) and vindication (v. 13). Doing the Law is so central in Paul's argument that even Gentiles

9..... And the Lord said unto Moses: "I know their contrariness and their thoughts and their stiffneckedness, and they will not be obedient till they confess their own sin their stiffneckedness, and they will not be obedient till they confess their own sin and the sin of their fathers. And after this they will turn to Me in all uprightness and with all (their) heart and with all (their) soul, and I will circumcise the foreskin of their heart and the foreskin of the heart of their seed, and I will create in them a holy spirit, and I will cleanse them so that they shall not turn away from Me from that day unto eternity. And their souls will cleave to Me and to all My commandments, and they will fulfil My commandments ..."' (Jubilees 1:22-25 in Charles 1913:12, [author's own emphasis]). who live according to the Law are considered as 'circumcision' (2:26) - even to the point that they would judge Ioudaioi who do not do the Law (v. 27). In line with the whole context of doing the Law and the Old Testament connotations attached to being circumcised in heart (see above), it is thus quite possible that what Paul is describing in 2:28-29 is simply a Ioudaios who does the Law on the basis of being inwardly capable of doing it. ${ }^{10}$ It may be objected that Paul's reference to ou grammati [not in letter] (2:29) would rule out such an interpretation, but ou grammati in this context alludes to the possession of the written Law (Dunn 1988:124; Hultgren 2011:130; Moo 1996:174 cf. gramma in v. 27) rather than to its observance.

However, if Paul has a fully Law-abiding Ioudaios in mind with his reference to being circumcised in heart in the spirit (2:28-29), it can be asked if he considers it possible to do the whole Law. This is exactly the question which he addresses in 3:9-20. There he emphatically places all people under sin without distinction (3:9). No one is righteous (3:10), seeks God (v. 11), shows kindness (v. 12) or lives righteously, peacefully or fearfully as the Law requires (v. 13-18). In 3:20, Paul states that 'now we know that whatever the law says, it speaks to those who are under the law, so that every mouth may be silenced, and the whole world may be held accountable to God' (NRSV). The human impossibility to perfectly adhere to the Law thus renders null and void its ability to serve as mark of righteousness or means of vindication. Only faith can bring about or mark off righteousness (3:21-35). With this larger picture of Paul's thought in mind, an allusion to circumcision in the heart (2:28-29) as fulfilling the Law would be indeed ironic and even paradoxical. Why would Paul radicalise Law-obedience in Romans 2 to such an extent, only to discard such a principle in 3:21-35?

While Westerholm (2004:258) also connects the circumcision of the heart in 2:28-29 to doing what the Law commands, he has a rather peculiar way of attempting to harmonise 2:13 with 3:21-35. He (Westerholm 2004:262-264) understands justification by faith as applicable to all sinners who could not fulfil the Law by their conduct, but rather than understanding the obedience to the Law as intrinsically impossible, he argues that not meeting the requirement of doing the Law is merely 'an accident of human history' (p. 260). The principle that someone can be justified through doing the Law is thus still in force for Paul. Although, such a notion can hardly be reconciled with Paul's general, absolutising language regarding the innate total depravity of all people (3:9-19), and is neither rescued by calling justification by faith an 'emergency measure introduced by God to offset human unrighteousness' (Westerholm 2004:262, [emphasis original]). There is nothing in the letter to the Romans that suggests that doing the Law is possible or that anyone could do the whole Law sometime in Paul's future.

10.While Barclay (1998:552-553) also connects the circumcision of the heart in $2: 28-29$ to the obedience of the Law, he sees it as being part of 'the new eschatological activity of the Spirit' (p. 554), a reading that he largely bases on Ezekiel 36:25-27. The concept of the circumcision of the heart is not explicit in the latter passage though (see the passages discussed above). 
Paul rather finds in the paradigmatic ' $\mathrm{I}$ ' a law that determines that any attempt to do good is met with evil that lies close at hand - a law that is at war with the law of the mind and captivates the ' $I$ ' to the law of sin within its members (7:21-23).

\section{An eschatological and salvation- historical contrast between Romans 2 and 3:21-35}

If 1:18 to 3:20 depict the condition of salvation and vindication of the Old Covenant in contrast with the condition of salvation and vindication of the New Covenant in 3:21-35 (Gispen 1950:264), the above-mentioned paradox (2:13 and 3:21-35) could not only be explained, but in fact shed light on the rhetorical structure of the letter to the Romans. Paul's rhetorical strategy in Romans 2 can then be described as radicalising obedience to such an extent that it becomes an impossible ideal, creating a plight (the inability to do the whole Law) that anticipates a solution (faith in Christ). Such an eschatological and salvation-historical contrast can in fact be derived from at least three indicators within the text of Romans 1 to 3:

1. The nuni [now] in 3:21 constitutes an eschatological and salvation-historical contrast of the old era with the new era in Christ (Matera 2010:96; Moo 1996:221-222; Osborne 2004:92-93; Schreiner [1998] 2005:180). ${ }^{11}$ In context, this nuni indicates the 'disclosure' (cf. NRSV) or 'revelation' (cf. ISV; Good News Bible; Lexham English Bible) of justification by faith in Christ of the new era in Christ (phaneroō; cf. the epiphany of faith in G1 3:23, 25; 4:4-5), which can be read as the eschatological turning point in Paul's exposition. That would place the preceding (esp. 1:18-3:20, including 2:28-29) and all identities involved within the domain of the old age before Christ, and the subsequent 3:21-31 and the involved identities in the new age in Christ. ${ }^{12}$

2. The old age is indicated by the expression 'under the

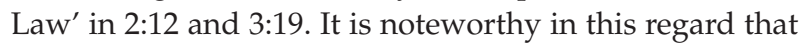
Paul seems to widen the domain of the Law in that he depicts Gentiles as having 'a law to themselves' (2:14). Moreover, in sequence of 3:9, which speaks of both Ioudaioi and Greeks being under sin, 3:19-20 denotes that

11.While these writers acknowledge a salvation-historical contrast here, they do not explicitly carry through its full implication, that is, they do not understand the doing and the keeping of the Law as solely being part of the means of justification in the old era under the Law.

12.While an eschatological reading of faith certainly converges with the approach of Campbell (2012:391-392), he reads faith in Romans predominantly as a theological indicative ('assurance') rather than as something to be appropriated, a notion that he bases on reading the much debated phrase pisteós 'lésou $(3: 22,26)$ as a subjective genitive ('the faith of Jesus, p. 392). The latter choice is related to his aversion to what he calls the 'western ordo' (Campbell 2012:386-389) of plight to solution. Apart from the fact that many recent interpreters read the phrase pisteo 'lēsou as denoting faith in Christ (an objective genitive, e.g. Moo 1996:224-226; 2013:44-48; Jewett 2007:275-279), 3:22b; 4:5, 9, 11, 12, 13, 14, 16, 17, 19 and 20 explicitly accentuates faith as human appropriation, rendering the reading 'the explicitly accentuates faith as human appropriation, rendering the reading the faith of Jesus' as unlikely. It is noteworthy that Paul never unambiguously refers to pistis [faith] as belonging to Christ (see esp. Silva 2004:227-234). While Campbel contests what he calls a 'contractual' mode of salvation (faith as appropriation) and proposes a covenantal mode of salvation (faith as gift, Campbell 2012:386-387, $392)$, his rather one-sided portrayal of faith has to be weighed against faith as opposed to works and wages $(4: 4-5)$, faith as access to grace $(5: 2)$ and faith in the lordship of Christ as access to salvation (10:11-13). Campbell's view of faith seems to verge on universalism.
Gentiles are included ('the whole world') in those 'under the Law', which pertains to 'whatever the Law speaks' (cf. the 'we' language in Gl 3:23). ${ }^{13}$ The Gentiles in the old era before the Christ event can thus be understood as being subjected to the same conditions for justification as Israel of the Old Testament, which awaited fulfilment in Christ. Such an idea is complemented by the fact that there was only one divinely revealed Law in the Old Testament available. ${ }^{14}$

3. In 3:1, Paul asks what the advantage of the Ioudaios is and what the value of circumcision is. However, if the Ioudaios in 2:28-29 pointed to a believer in Christ and not to an actual Ioudaios in the Old Covenant as such, 2:28-29 would be an interruption to Paul's argument. It fits the rhetorical flow of Paul's argument more naturally if 2:28-29 remains within the identity of the Ioudaios right up to 3:3. Additionally, the type of questions asked in 3:1 implies that the preceding (including 2:28-29) sketches a picture of being a Ioudaios that is not more advantageous than being a Gentile - a notion that would stand in conflict with the idea that someone in Christ is, in a way, a true Ioudaios. The questions in 3:1 thus strengthen the notion that 2:17-29 pictures the unattainable ideal of the identity of a Ioudaios before or without faith in Christ. The logic between the lines would thus be as follows: Since the Ioudaioi do not keep the whole Torah (2:17-27) and they are not circumcised in heart in their spirit (2:28-29), Paul asks in 3:1 what is then the advantage of the Ioudaios or what the value of circumcision is.

If the ideal Ioudaios is portrayed in 2:28-29, it would make the contrast with the total corruptness of all people (including the Ioudaioi) and their inability to fulfil the Law in 3:1-20 stark and effective. Such an ideal picture of how Ioudaioi ought to be would implicitly prompt for a solution: firstly, to repent of their inability to fulfil the Law, which is real humbleness (Lv 26:41, see above), and secondly, to accept Christ as Messiah in faith. Understood in this way, Paul's image of the ideal Ioudaios would be an implicit rhetorical appeal for Ioudaioi to accept Christ, for he is the only one who fits that ideal picture (cf. 3:25-26). At the same time, the exposition in Romans 2 to 3 can be interpreted as an explanation for the era of faith in Christ that had to come, and for the necessity of the means of salvation and justification in the Old Covenant to be fulfilled, completed and replaced by faith in Christ as a new means of salvation and justification. ${ }^{15}$

13.Gispen (1950:264) argues that Leviticus $18: 5$ was probably understood as representing the standard for more than Israel - a principle that implicated all people.

14.Although Westerholm (2004:259) acknowledges Gentiles being under the same Law as the loudaioi, he understands this situation as being in force even after the Christ event, and thus not so much as an era that is fulfilled in salvation history.

15.In this approach it could be asked what happens to Israel of the Old Testament. Are they saved? As argued elsewhere, Paul could in fact answer that exact question in 11:26 where he points to the salvation of 'all Israel'. Such a reading would be possible if the future tense (sōthesetai [will be saved]) is read as a logical future, possible if the future tense (sothesetai [will be saved]) is read as a logical future,
logically following the prophetic references in $11: 26 b-27$, but not necessarily lying in Paul's actual future see (Du Toit 2015). 


\section{Answering possible objections in the light of the New Perspective on Paul}

It could rightly be argued that the Ioudaioi, in the time of the second temple, cannot be typified as legalistic in an unqualified sense (e.g. Dunn 1988; Sanders 1977). Although final vindication on the basis of doing the Law did exist in the time of the second temple (Gathercole 2002:37-90), and although nomism was more varied than early proponents of the NPP contended (Carson, O'Brien \& Seifrid 2001, 2004), it is not necessarily Paul's aim in Romans 2 to depict all Ioudaioi as legalistic or as focusing on justification by works. Neither is Paul trying to portray the whole of the Old Testament teaching on justification or salvation as if the only prevalent understanding in the time of the second temple was that the Law must be fully obeyed in order to obtain eternal life or vindication. Yet, although Paul's focus on obeying the Law for vindication was not against the teaching of the Old Testament on these subjects, because texts such as Leviticus 18:5, Deuteronomy 30 and Ezekiel 20:11, 13, 21 could be understood in this way (see above), that was probably not the main point of Paul's rhetoric.

The main point of Paul's rhetoric was rather to radicalise Law-obedience to such an extent that it would make faith in Christ for salvation or vindication absolutely necessary for all people, including all Ioudaioi. In addition, Paul would want to contrast the means of salvation and justification of the old era before Christ (works and Law-obedience) with the means of justification in the new era in Christ (faith). If understood in this way, Romans 2 to 3 could form part of a rather apologetic response to some who might have questioned the validity of his all-inclusive gospel of faith, including Ioudaioi. ${ }^{16}$

It could be objected that such a reading of Romans 2 to 3 would portray the Ioudaioi in a too negative way. Yet, such a reading could hardly be interpreted as against the Ioudaioi exclusively, because Gentiles are included in Paul's exposition: they are also subjected to the requirement to do the Law (2:14, 26 and 3:19 by implication). Paul is not arguing against the identity of the Ioudaioi as such, but against any identity before or outside Christ. The whole world is accountable to God (3:19). All people have sinned and fall short of God's glory (3:23). All people are affected by the old era under the Law and are in need of salvation and justification by faith.

\section{Conclusion}

In conclusion, Paul's appeal to the doing of the Law in Romans 2 in order to obtain eternal life (v. 7), honour and

16.Although the letter to the Romans is generally seen as being written to Gentil believers, most agree that some loudaioi were present in the congregation (e.g. Priscilla and Aquila according to 16.3, see Moo 1996:13, Longenecker 2011:75-78). Yet, the logic behind a more general apologetic could lie in Paul's relative unfamiliarity with the congregation $(15: 21-24)$ and the possibility of the letter also being intended to be read by other loudaioi. peace (v. 10) and/or justification (v. 13) can be understood as pointing to the conditions of salvation and justification pertaining to the old era under the Law before the Christ event. In 3:21-35 the condition of justification of the new era in Christ (faith) is then contrasted to the former conditions pertaining to the old era before the Christ event (doing the Law). The prerequisite to do the whole Law is thus not understood as theoretical or hypothetical as in the regular reformed view (first approach above), but as actual, yet as redundant due to its salvation-historical fulfilment in Christ. The contradiction between 2:13 and 3:21 is thus retained, but explained as pertaining to two separate salvation-historical eras - a distinction that is not always articulated or developed to its full consequence within the structure of Romans 1-3 in reformed approaches.

Although Paul later implies that the 'law' of the Spirit of life in Christ has freed believers from the Law of sin and death (8:4), and Paul might hint at such a fulfilment in 2:28-29, Romans 2 is not understood as portraying such a fulfilment from the perspective of belief in Christ. The whole of Romans 2 rather focuses on the literal doing of the whole Law, which Paul portrays as principally being applicable to all people, including Gentiles (esp. 2:14,26). Because of the impossibility for anyone to do the whole Law and the effects of sin on all people (3:4-20), the scenario Paul sketches in Romans 2 thus necessitates faith in Christ.

The latter can be understood as being part of Paul's rhetorical strategy, constituting the plight of someone under the Law, necessitating a solution. In Paul's rhetoric he radicalises obedience to the Law in the Old Testament to the point of obtaining salvation and justification by doing it. Yet, while such a teaching is not inconsistent with the Old Testament itself, it serves the purpose of portraying the means of justification and salvation of the Old Testament as impossible and therefore as redundant. Being a rhetorical strategy in the build-up of the letter to the Romans, such a reading of Romans 2 does not imply that Paul does not teach that doing good is part of a Christ-believer's life. Such doing is not originating from an old existence under the reign of the Law, but originates from a new existence in the Spirit within the new eschatological existence in Christ $(6: 14-18 ; 8: 1-14)$, which is free from the Law (7:1-6). Although the Ioudaios in Romans 2 is portrayed in a negative way, it is not intended to demean the identity of the Ioudaios as such, or to give a complete account of the beliefs of the the second temple's Ioudaioi, but forms part of Paul's rhetorical strategy to portray all people in the old era under the Law as being under sin and therefore in need of justification by faith.

\section{Acknowledgements Competing interests}

The author declares that he has no financial or personal relationships which may have inappropriately influenced him in writing this article. 


\section{References}

Barclay, J.M.G., 1998, 'Paul and Philo on Circumcision: Romans 2.25-9 in social and cultural context', New Testament Studies 44, 536-556. http://dx.doi.org/10.1017/ S0028688500016714

Barrett, C.K., [1962] 1975, A Commentary on the Epistle of Romans, Adam \& Charles Black, London. (Black's New Testament Commentaries).

Bauer, W., Danker, F.W., Arndt, W.F. \& Gingrich, F.W. (eds.), 2000, A Greek-English Lexicon of the New Testament and Other Early Christian Literature (BDAG), University of Chicago Press, Chicago, IL.

Bruce, F.F., [1985] 2008, Romans, Inter Varsity Press, Downers Grove, IL. (Tyndale New Testament Commentaries).

Calvin, J., 2016, Commentaries on the Epistle of Paul the Apostle to the Romans, Christian Classics Ethereal Library, Grand Rapids, MI, viewed 16 March 2016, from http://www.ccel.org/ccel/calvin/calcom38.pdf

Campbell, D.A., 2012, 'An Apocalyptic Rereading of "Justification" in Paul: Or, an overview of the argument of Douglas Campbell's The Deliverance of God', The Expository Times 123(8), 382-393. http://dx.doi.org/10.1177/0014524612439970

Carras, G.P., 1992, 'Romans 2:1-29: A Dialogue on Jewish Ideals', Biblica 73, 183-207.

Carson, D.A., O'Brien, P.T. \& Seifrid, M.A. (eds.), 2001, Justification and Variegated Nomism: The Complexities of Second Temple Judaism, vol. 1, Mohr Siebeck, Tubingen/Baker Academic, Grand Rapids, MI.

Carson, D.A., O'Brien, P.T. \& Seifrid, M.A. (eds.), 2004, Justification and Variegated Nomism: The Paradoxes in Paul, vol. 2, Mohr Siebeck, Tubingen/Baker Academic, Grand Rapids, MI.

Charles, R.H. (ed.), 1913, The Apocrypha and Pseudepigrapha of the Old Testament in English, vol. 2, Clarendon, Oxford.

Craigie, P.C., [1976] 1983, The Book of Deuteronomy, Eerdmans, Grand Rapids, MI. (The New International Commentary on the Old Testament).

Cranfield, C.E.B., 1975, The Epistle to the Romans, T\&T Clark, Edinburgh. (The International Critical Commentary, 1).

Dunn, J.D.G., 1988, Romans 1-8, Word Books, Dallas, TX. (Word Biblical Commentary, 38a).

Du Toit, P. La G., 2015, 'The Salvation of "All Israel" in Romans 11:25-27 as the Salvation of Inner-Elect, Historical Israel in Christ', Neotestamentica 49(2), 417-452. http://reference.sabinet.co.za/document/EJC188227

Ervin, H.M., 1984, Conversion-initiation and the Baptism in the Holy Spirit: A Critique of James D.G. Dunn, Baptism in the Holy Spirit, Hendrickson, Peabody, MA.

Fitzmyer, J.A., 1993, Romans, Doubleday, New York. (The Anchor Bible).

Gathercole, S.J., 2002, Where is boasting? Early Jewish Soteriology and Paul's Response in Romans 1-5, Eerdmans, Grand Rapids, MI.

Gispen, W.H., 1950, Het Boek Leviticus, Kok, Kampen. (Commentaar op het Oude Testament).

Harrison, R.K., [1973] 1974, Jeremiah and Lamentations, InterVarsity, London. (Tyndale Old Testament Commentaries).

Hartley, J.E., 1992, Leviticus, Word Books, Dallas, TX. (Word Biblical Commentary).

Hultgren, A.J., 2011, Paul's letter to the Romans: A Commentary, Eerdmans, Grand Rapids, MI.

Jewett, R., 2007, Romans: A Commentary, Fortress, Minneapolis, MN. (Hermeneia).

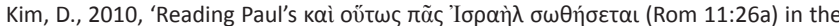
Context of Romans', Calvin Theological Journal 45(2), 317-334.

Longenecker, R.N., 2011, Introducing Romans: Critical issues in Paul's most famous letter, Eerdmans, Grand Rapids, MI.

Matera, F.J., 2010, Romans, Baker Academic, Grand Rapids, MI. (Paideia Commentaries on the New Testament).

Merrill, E.H., 1994, Deuteronomy, B\&H Publishing, Nashville, TN, ePub ed. (The New American Commentary).

Milgrom, J., 2004, Leviticus: A Book of Ritual and Ethics, Fortress, Minneapolis, MN. (Continental Commentaries).

Moo, D.G., 1996, The Epistle to the Romans, Eerdmans, Grand Rapids, MI. (The New International Commentary on the New Testament).

Moo, D.G., 2013, Galatians, Baker Academic, Grand Rapids, MI. (Baker Exegetical Commentary on the New Testament).

Nanos, M., 2014, 'Paul's Non-Jews do not become "Jews," but do they become "Jewish"?: Reading Romans 2:25-29 Within Judaism, Alongside Josephus', Journal of the Jesus Movement in its Jewish Setting 1, 26-53.

Ortlund, D.C., 2009, 'Justified by faith, Judged according to works: Another look at a Pauline Paradox', Journal of the Evangelical Theological Society 52(2), 323-339.

Osborne, G.R., 2004, Romans, IVP Academic, Downers Grove, IL. (The IVP New Testament Commentary Series).

Ridderbos, H., 1959, Aan de Romeinen, Kok, Kampen. (Commentaar op het Nieuwe Testament).

Rooker, M.F., 2000, Leviticus, B\&H Publishing, Nashville, TN, ePub ed. (The New American Commentary).

Sailhamer, J.H., 1992, The pentateuch as narrative: A Biblical-Theological Commentary, Zondervan, Grand Rapids, MI.

Sanders, E.P., 1977, Paul and Palestinian Judaism: A Comparison of Patterns of Religion, SCM, London.

Sanders, E.P., 1983, Paul, the law and the Jewish people, Fortress Press, Philadelphia, PA.

Schreiner, T.R., [1998] 2005, Romans, Baker Academic, Grand Rapids, MI, ePub ed. (Baker Exegetical Commentary on the New Testament).

Silva, M., 2004, 'Faith versus works of law in Galatians', in D.A. Carson, P.T. O'Brien \& M.A. Seifrid (eds.), Justification and Variegated Nomism: The Paradoxes in Paul, vol. 2, pp. 217-248, Mohr Siebeck, Tubingen/Baker Academic, Grand Rapids, MI.

Theissen, M., 2014, 'Paul's Argument against Gentile Circumcision in Romans 2:17-29', Novum Testamentum 56, 373-391. http://dx.doi.org/10.1163/15685365-12341488

Thielman, F., 1989, From plight to solution: A Jewish framework for understanding Paul's view of the law in Galatians and Romans, Brill, Leiden.

Thompson, J.A., 1980, The Book of Jeremiah, Eerdmans, Grand Rapids, MI. (The New International Commentary of the Old Testament).

Westerholm, S., 2004, 'The Righteousness of the law and the Righteousness of faith in Romans', Interpretation 58(3), 253-264. http://dx.doi.org/10.1177/ 002096430405800304

Wright, N.T., 2001, 'The Law in Romans 2', in J.D.G. Dunn (ed.), Paul and the Mosaic Law, pp. 131-150, Eerdmans, Grand Rapids, MI.

Wright, N.T., 2002, 'The letter to the Romans: Introduction, commentary, and reflections', in L.E. Keck (ed.), The new interpreter's Bible, vol. 10, pp. 394-770, Abingdon Press, Nashville, TN. 